\title{
The impact of different commercial yeasts on quality parameters of Montenegrin red wine - Vranac and Kratošija
}

\author{
Sanja ŠUĆUR ${ }^{1 *}$, Vesna MARA $\check{S}^{1}$, Vesna KODŽULOVIĆ́ ${ }^{1}$,Jovana RAIČEVIĆ ${ }^{1}$, Milena MUGOŠA ${ }^{1}$, Tjaša JUG $^{2}$ and Tatjana KOŠMERL \\ 1"13. Jul Plantaže”, Sector for Development, Put Radomira Ivanovića 2, 81000 Podgorica, Montenegro \\ ${ }^{2}$ Agriculture and Forestry Institute, Pri hrastu 18, 5000 Nova Gorica, Slovenia \\ ${ }^{3}$ Biotechnical Faculty, University of Ljubljana, Jamnikarjeva 101, 1000 Ljubljana, Slovenia
}

\begin{abstract}
The influence of three different commercial yeasts (BDX, BM4X4 and ICV D21), on quality parameters of wines from varieties Vranac and Kratošija were studied during two consecutive vintage years. The basic quality parameters of grape must (sugar content, total acidity, $\mathrm{pH}$, tartaric and malic acid) and the wine quality parameters (alcohol content, total dry extract, glycerol, $\mathrm{pH}$, total polyphenols and total anthocyanins) were determined after each phase of vinifications: after alcoholic and malolactic fermentation as well as after three months of wine maturation. There are significant differences in quality parameters of grapes and wines between vintages 2012 and 2013. Higher content of total dry extract and glycerol in wines after completion of alcoholic fermentation was achieved in vintage 2013. In vintage 2013, the highest content of total polyphenols $\left(3.75\right.$ and $\left.2.98 \mathrm{~g} \mathrm{~L}^{-1}\right)$ and anthocyanins $\left(1247\right.$ and $\left.713 \mathrm{mg} \mathrm{L}^{-1}\right)$ in Vranac wine after malolactic fermentation and after three months of maturation, were achieved by yeast BM4X4, while the highest total polyphenols (2.14 and $\left.1.92 \mathrm{~g} \mathrm{~L}^{-1}\right)$ and anthocyanins content (527 and $262 \mathrm{mg}$ $\mathrm{L}^{-1}$, respectively) was achieved by BDX strain in Kratošija wine. The results of sensory analysis showed no significant differences between the used yeast strains and studied. Surprisingly, the wines of vintage 2012 are even slightly better sensory evaluated.
\end{abstract}

\section{Introduction}

Wine styles are defined by complex and highly diverse chemical compositions. Amongst the myriad of grape and wine processing options known to influence wine style, choice of yeast strain represents a low-cost opportunity to broaden the spectrum of wine flavour profiles possible from a single vineyard or variety [1]. There are hundreds of different commercially available wine yeast strains that, potentially, provide a means by which winemakers can tailor their wines for different consumer market segments. Saccharomyces cerevisiae is a yeast species specialized in metabolizing media with high sugar contents and small quantities of nitrogenous compounds. In the past, musts were fermented by yeast indigenous to the grape microbiota, but nowadays most are inoculated with selected yeast strains preserved in dried form. Traditionally, yeasts have been selected for their fermentative power, suitable fermentative kinetics at different temperatures, low acetic production and resistance to sulphur dioxide. However, new selection criteria emerged and role of yeasts in winemaking involved improvement of wine in terms of their colour, aroma, structure and other technological properties $[2,3]$ concluded that the role of yeast is complex and strongly associated with wine quality, and that it is becoming even more important to select yeast that are right for each kind of wine, region and even microclimate.

Wine phenolics are extracted from grape skins and seeds during fermentation, interact with insoluble cell wall material from the grapes [4,5], and undergo a range of chemical transformations during maturation. Selection of yeast strain has been shown to impact on the concentration of anthocyanins [6,7] and other phenolics [6,8,9] in finished wine. The work combined analyses of wine total polyphenols, total anthocyanins, total dry extract, alcohol and sensory analysis. The impact of yeast upon wine sensory properties in red wine play a role in the perception of red and dark fruit aromas [10,11]. Also, yeasts have great influence on glycerol production which is influenced by many growth and environmental factors [12]. Several studies have described the effect of yeast strain on glycerol production $[13,14]$ and it appears to be one of the key factors impacting glycerol production. The amount of glycerol produced varies with the type of yeast used, with sugar content and the grape variety. This manuscript describes the results of four fermentation experiments with different commercial yeasts, across two vintages and within two grape varieties, which emphasize the significant impact that choice of yeast strain can have upon red wine chemical composition.

Current viticulture and wine production in Montenegro is based mainly on presumed autochthonous grapevine cultivars, such as Vranac, Kratošija, Krstač, and Žižak. The dominant cultivars for red wine production are Vranac and Kratošija. Significantly less prevalent is Krstač, used for white wine production, while no commercial wine is produced from Žižak. Vranac and Kratošija are the most important grapevine varieties for production of red wines in Montenegro.

Correspondence to: Sanja ŠUĆUR, “13. Jul Plantaže”, Sector for Development, Put Radomira Ivanovića 2, 81000 Podgorica, Montenegro; E-mail: sucursanja@yahoo.com

Key words: autochthonous varieties, wine, yeast, quality, sensory

Received: November 10, 2016; Accepted: November 25, 2016; Published: November 28, 2016 
Vranac wine became a national brand as well as the most recognizable and the best product of the company "13. Jul Plantaže". Kratošija is a Montenegrin autochthonous variety for production of red wines, grown for centuries in Montenegro, which falls into the category of recommended varieties for quality wine. According to many literature data, Kratošija variety appeared earlier and was introduced into cultivation quite earlier than Vranac [15]. Wines of these varieties are of premium quality, Vranac has dark red ruby colour, full body, fruity taste and pleasant astringency and it has potential of lying down and maturing. Kratošija wine is characterized by an intense ruby-red colour and aroma of red berry fruits and an extremely pleasant taste; it has a light and harmonious structure and smooth finish.

\section{Material and methods}

The trial was carried out during the 2012 and 2013 growing seasons. Autochthonous grapevine varieties Vranac and Kratošija were planted in the commercial vineyard of the company "13. Jul Plantaže" in the Cemovsko field in sub-region Podgorica (Montenegro).

Grapes of both varieties were planted in 2003, grafted onto Paulsen 1103 rootstock, trained to a modified single Guyot training system, rows spaced $2.6 \mathrm{~m}$ apart and with $0.7 \mathrm{~m}$ between plants in the row. All standard agro-technical operations were applied and vineyards were in good and healthy condition. Wines were produced at microvinification scale in the experimental cellar at the company "13. Jul Plantaže". At harvest, grapes from both examined varieties were harvested manually and transported to the experimental cellar. Alcoholic fermentation of trials was performed in PVC barrels using traditional method. For the vinification of control wines, an average grape sample of both varieties was $100 \mathrm{~kg}$ of grapes. For trials with yeast addition we used an average grape sample of $400 \mathrm{~kg}$ for both varieties. Potassium metabisulphite,

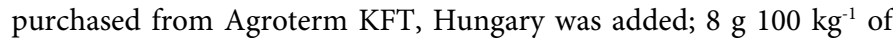
grapes from both varieties. All enzyme, wine yeasts, lactic acid bacteria and yeast nutrients were obtained from Lallemand, Australia. Three commercial yeasts, dominantly used for production of red wines, were chosen to induce alcoholic fermentation. Within all varieties commercial yeasts that were used are: Enoferm BDX, Lalvin BM4x4 and Lalvin ICV D21 $\left(30 \mathrm{~g} \mathrm{hL}^{-1}\right)$. Enzyme Lalvin EX-V for maceration $\left(2 \mathrm{~g} 100 \mathrm{~kg}^{-1}\right)$ and yeast nutrient Go-Ferm Protect $\left(30 \mathrm{~g} \mathrm{hL}^{-1}\right)$ were added during vinification, while yeast nutrient Fermaid E $\left(25 \mathrm{~g} \mathrm{hL}^{-1}\right)$ was added during fermentation. After alcoholic fermentation; wines were racked and malolactic fermentation without addition of lactic acid bacteria (LAB) was performed. After completion of malolactic fermentation wines were racked and potassium metabisulfite was added in amount depending of free $\mathrm{SO}_{2}$ in analysed wine samples.

For determination of basic wine chemical parameters: alcohol, total dry extract and $\mathrm{pH}$ value, the reference methods of European Union [16] were used. Total polyphenols and anthocyanins content were determined by spectrophotometer. Total polyphenols were quantified by Folin-Ciocalteu index method (Compendium of international methods of wine and must analysis-OIV, 2014). The total anthocyanins were determined using the $\mathrm{pH}$ differential method [17]. Content of alcohol, total dry extract and glycerol in wine was determined using wine analysis instrument WineScan ${ }^{\mathrm{TM}}$ FT 120 (FOSS). Each sample of wine was judged by the experienced sensory panel for colour, aroma and taste intensity and quality, body, aftertaste, harmony and general sensation using an official OIV 100-points scale.

\section{Results and discussion}

\section{Grape quality}

Quality parameters of examined grape varieties are shown in Table 1. Vranac variety is known as variety with high total anthocyanin content, what is confirmed in this research. Vranac accumulated higher content of sugar in 2013, with higher total acidity and tartaric acid content. There are no differences between $\mathrm{pH}$ and malic acid content between years. There are significant differences of total polyphenols and anthocyanins content between years, which can be explained by different clime conditions during vintages time. [18] reported that lower temperatures were during grape ripening in vintage 2012, than in 2013, that can influence total polyphenols and anthocyanins content in grape, as well as and sugar content. Similar situation is noticed within Kratošija variety. Kratošija also accumulated higher content of sugar in 2013, with higher total acidity, tartaric and malic acid content. High acidity is varietal characteristic of Kratošija variety. In average, Kratošija accumulates high content of sugar and low anthocyanins content.

\section{After alcoholic fermentation}

Higher content of total dry extract and glycerol in wines after completion of alcoholic fermentation was achieved in vintage 2013 (Table 2).

Table 1. Quality parameters of Vranac and Kratošija grapes.

\begin{tabular}{|c|c|c|c|c|c|c|c|c|}
\hline Grape variety & Harvest season & Sugar (\%) & $\begin{array}{l}\text { Total acidity } \\
\quad\left(\mathrm{g} \mathrm{L}^{-1}\right)\end{array}$ & $\begin{array}{l}\text { Tartaric acid } \\
\quad\left(\mathrm{g} \mathrm{L}^{-1}\right)\end{array}$ & pH & $\begin{array}{l}\text { Malic acid } \\
\quad\left(\mathrm{g} \mathrm{L}^{-1}\right)\end{array}$ & $\begin{array}{c}\text { Total polyphenols } \\
\left(\mathrm{g} \mathrm{L}^{-1}\right)\end{array}$ & $\begin{array}{l}\text { Total anthocyanins } \\
\qquad\left(\mathrm{mg} \mathrm{L}^{-1}\right)\end{array}$ \\
\hline Vranac & 2012 & 18.8 & 3.61 & 4.84 & 3.70 & 1.10 & 0.12 & 19.5 \\
\hline Vranac & 2013 & 21.2 & 4.63 & 5.49 & 3.70 & 1.00 & 0.93 & 205.5 \\
\hline Kratošija & 2012 & 21.5 & 5.73 & 3.64 & 3.60 & 1.80 & 0.49 & 60.0 \\
\hline Kratošija & 2013 & 22.6 & 6.23 & 4.05 & 3.59 & 3.00 & 0.45 & 21.0 \\
\hline
\end{tabular}

Table 2. Chemical parameters after alcoholic fermentation for Vranac and Kratošija wine.

\begin{tabular}{|c|c|c|c|c|c|c|c|}
\hline \multirow[t]{2}{*}{ Variety } & \multirow[t]{2}{*}{ Yeast } & \multicolumn{2}{|c|}{$\begin{array}{l}\text { Alcohol } \\
\text { (vol. \%) }\end{array}$} & \multicolumn{2}{|c|}{$\begin{array}{c}\text { Total dry extract } \\
\left(\mathrm{g} \mathrm{L}^{-1}\right)\end{array}$} & \multicolumn{2}{|c|}{$\begin{array}{c}\text { Glycerol } \\
\left(\mathrm{g} \mathrm{L}^{-1}\right)\end{array}$} \\
\hline & & 2012 & 2013 & 2012 & 2013 & 2012 & 2013 \\
\hline \multirow[t]{4}{*}{ Vranac } & Control & 12.59 & 13.38 & 24.20 & 29.62 & 8.19 & 11.21 \\
\hline & BDX & 12.41 & 13.69 & 25.03 & 30.40 & 9.18 & 10.56 \\
\hline & D21 & 12.48 & 14.04 & 24.07 & 31.16 & 8.37 & 10.44 \\
\hline & BM4x4 & 12.48 & 13.98 & 24.57 & 30.52 & 8.37 & 10.07 \\
\hline \multirow[t]{4}{*}{ Kratošija } & Control & 13.58 & 13.01 & 24.28 & 28.69 & 9.18 & 10.58 \\
\hline & BDX & 13.84 & 13.08 & 26.28 & 28.37 & 9.22 & 9.11 \\
\hline & D21 & 13.84 & 13.24 & 24.69 & 29.30 & 8.24 & 9.17 \\
\hline & BM4x4 & 13.77 & 13.11 & 26.04 & 28.15 & 8.69 & 8.34 \\
\hline
\end{tabular}


Table 3. Total polyphenols and total anthocyanins contents after alcoholic fermentation for Vranac and Kratošija wine.

\begin{tabular}{|c|c|c|c|c|c|}
\hline \multirow[t]{2}{*}{ Variety } & \multirow[t]{2}{*}{ Yeast } & \multicolumn{2}{|c|}{$\begin{array}{c}\text { Total polyphenols } \\
\left(\mathrm{g} \mathrm{L}^{-1}\right)\end{array}$} & \multicolumn{2}{|c|}{$\begin{array}{l}\text { Total anthocyanins } \\
\left(\mathrm{mg} \mathrm{L}^{-1}\right)\end{array}$} \\
\hline & & 2012 & 2013 & 2012 & 2013 \\
\hline \multirow[t]{4}{*}{ Vranac } & Control & 2.62 & 2.20 & 862 & 729 \\
\hline & BDX & 3.05 & 3.75 & 1247 & 1229 \\
\hline & D21 & 2.81 & 3.73 & 889 & 1158 \\
\hline & BM4x4 & 2.35 & 3.67 & 766 & 1260 \\
\hline \multirow[t]{4}{*}{ Kratošija } & Control & 1.30 & 1.28 & 310 & 330 \\
\hline & BDX & 1.86 & 2.06 & 415 & 516 \\
\hline & D21 & 1.91 & 2.14 & 526 & 577 \\
\hline & BM4x4 & 1.92 & 1.87 & 453 & 523 \\
\hline
\end{tabular}

Table 4. Chemical parameters and sensory evaluation in Vranac and Kratošija wine.

\begin{tabular}{|c|c|c|c|c|c|c|c|c|c|c|c|}
\hline \multirow[t]{2}{*}{ Variety } & \multirow[t]{2}{*}{ Yeast } & \multicolumn{2}{|c|}{$\begin{array}{l}\text { Alcohol } \\
\text { (vol. \%) }\end{array}$} & \multicolumn{2}{|c|}{$\begin{array}{l}\text { Total dry extract } \\
\qquad\left(\mathrm{g} \mathrm{L} \mathrm{L}^{-1}\right)\end{array}$} & \multicolumn{2}{|c|}{$\begin{array}{l}\text { Total polyphenols } \\
\left(\mathrm{g} \mathrm{L}^{-1}\right)\end{array}$} & \multicolumn{2}{|c|}{$\begin{array}{l}\text { Total anthocyanins } \\
\left(\mathrm{mg} \mathrm{L}^{-1}\right)\end{array}$} & \multicolumn{2}{|c|}{ Sensory analysis (score) } \\
\hline & & 2012 & 2013 & 2012 & 2013 & 2012 & 2013 & 2012 & 2013 & 2012 & 2013 \\
\hline \multirow[t]{4}{*}{ Vranac } & Control & 12.53 & 12.94 & 23.70 & 29.70 & 1.63 & 1.95 & 595.5 & 522.0 & 72.33 & 71.50 \\
\hline & BDX & 12.44 & 13.33 & 26.10 & 30.05 & 1.68 & 2.32 & 463.5 & 574.5 & 77.00 & 75.60 \\
\hline & D21 & 12.43 & 13.84 & 24.80 & 29.40 & 2.21 & 2.98 & 508.5 & 730.5 & 77.00 & 76.90 \\
\hline & BM4x4 & 12.53 & 13.84 & 24.20 & 30.70 & 2.31 & 2.42 & 427.5 & 522.0 & 74.33 & 75.00 \\
\hline \multirow[t]{4}{*}{ Kratošija } & Control & 13.44 & 12.81 & 24.20 & 27.04 & 1.28 & 1.33 & 132.0 & 222.0 & 71.00 & 70.00 \\
\hline & BDX & 13.69 & 12.91 & 26.10 & 27.60 & 1.93 & 1.92 & 136.5 & 262.5 & 72.67 & 71.50 \\
\hline & D21 & 13.70 & 12.95 & 26.10 & 28.10 & 1.37 & 1.33 & 180.0 & 258.0 & 80.70 & 79.00 \\
\hline & BM4x4 & 13.90 & 12.73 & 25.50 & 26.10 & 1.71 & 1.75 & 181.5 & 186.0 & 79.60 & 78.00 \\
\hline
\end{tabular}

After alcoholic fermentation, there were no significant differences in achieved alcohol content between used commercial yeast and control wine as well. In the vintage of 2013 the highest content of total dry extract was achieved by D21 yeast in both varieties, while in 2012 it was by BDX yeast.

Higher content of total polyphenols and anthocyanins is characteristic of Vranac variety, comparing to Kratošija which achieves significantly lower content of these compounds. Higher content of these compounds in wines after completion of alcoholic fermentation was also achieved in vintage 2013 (Table 3). There were no significant differences between BDX and D21 used yeast in total polyphenols content for both vintages in Vranac wines. In the vintage of 2013 there were not also significant differences between used yeast in achieved content of total anthocyanins, while control wine had much lower anthocyanins content. In 2012 vintage BDX yeast significantly stressed out in achieving anthocyanins content, while control wine and wine with other yeast had similar anthocyanins content values. Regarding to Kratošija wine, in this phase wine where D21 commercial yeast were used, showed the highest potential in accumulation of total polyphenols and anthocyanins in both vintages. Also, control wines had significantly lower content of these compounds for both vintages. However, these data are susceptible to changes and in these phase, cannot be considered as final indicator if wine quality.

\section{After maturation}

In vintage 2013, the highest content of total dry extract, total polyphenols and total anthocyanins of Vranac wine after malolactic fermentation and after three months of maturation, were achieved by yeast BM4X4 (Table 4). There were no significant differences between alcohol content within treatments. Wines from 2012 are slightly better sensory evaluated and it is shown that D21 and BDX yeast had similar and significantly higher evaluating marks. The lowest sensory evaluation showed control wine. In Kratošija wine the highest total polyphenols and anthocyanins content was achieved by BDX yeast in vintage 2013, while in 2012 the best results showed commercial yeast D21. Regarding to sensory evaluation it is shown that the highest marks got wines where $\mathrm{D} 21$ and $\mathrm{BM} 4 \mathrm{x} 4$ were used.

\section{Conclusion}

Results of this study highlight the importance of different commercial yeast inoculation as a tool to modulate red wine composition. Regarding to Vranac wine, it is noticed that inoculation with yeast BM4X4 gave wine with highest total polyphenol and total anthocyanin content, while wine with commercial yeasts BDX had the highest total dry extract content. As sensory characteristics are the most important, we concluded that D21 and BDX improved Vranac wine flavour and aroma. In Kratošija wine the highest total polyphenols and anthocyanins content was achieved by BDX yeast in vintage 2013, while in 2012 the best results showed commercial yeast D21. Regarding to sensory evaluation it is shown that the highest score got wines produced by $\mathrm{D} 21$ and BM4x4 yeasts.

In conclusion, by taking a broad approach to characterising the impacts of different wine yeasts on red wine composition we demonstrate a clear wine yeast impact 'signature' despite using different grapes from different vintages. The use of commercial strains of $S$. cerevisiae is becoming a common practice in winemaking. This practice ensures a reproducible product, reduces the risk of wine spoilage and allows a more predictable control of fermentation and quality.

\section{References}

1. Cordente AG, Curtin CD, Varela C, Pretorius IS (2012) Flavour-active wine yeasts Appl Microbiol Biotechnol 96: 601-618. [Crossref]

2. Suárez Lepe JA, Iñigo Leal B (2004) In Oenological Microbiology. Winemaking Basics, 422-424. Madrid: Mundi-Prensa.

3. Suárez-Lepe JA, Morata A (2012) New trends in yeast selection for winemaking. Trends in Food Science \& Technology 23: 39-50.

4. Bindon KA, Smith PA, Kennedy JA (2010) Interaction between grape-derived proanthocyanidins and cell wall material. 1 . Effect on proanthocyanidin composition 
and molecular mass. J of Agric Food Chem 58: 2520-2528. [Crossref]

5. Bindon KA, Smith PA, Holt H, Kennedy JA (2010) Interaction between grape-derived proanthocyanidins and cell wall material. 2. Implications for vinification. J Agric Food Chem 58: 10736-10746.[Crossref]

6. Monagas M, Gomez-Cordoves C, Bartolome B (2007) Evaluation of differen Saccharomyces cerevisiae strains for red winemaking. Influence on the anthocyanin, pyranoanthocyanin and non-anthocyanin phenolic content and colour characteristics of wines. Food Chemistry 104: 814-823.

7. Morata A, Gómez-Cordovés MC, Calderón F, Suárez JA (2006) Effects of pH, temperature and $\mathrm{SO} 2$ on the formation of pyranoanthocyanins during red wine fermentation with two species of Saccharomyces. Int J Food Microbiol 106: 123-129. [Crossref]

8. Sidari R, Postorino S, Caparello A, Caridi A (2001) Evolution during wine aging of color and tannin differences induced by wine starters. Annals of Microbiology 57: 197-201.

9. Torrens J, Urpí P, Riu-Aumatell M, Vichi S, López-Tamames E, Buxaderas S (2008) Different commercial yeast strains affecting the volatile and sensory profile of cava base wine. Int J of Food Microbiol 124: 48-57. [Crossref]

10. Escudero A, Campo E, Farina L, Cacho J, Ferreira V (2007) Analytical characterization of the aroma of five premium red wines. Insights into the role of odor families and the concept of fruitiness of wines. J of Agric Food Chem 55: 4501-4510. [Crossref]

11. Pineau B, Barbe JC, Van Leeuwen C, Dubourdieu D (2009) Examples of perceptive interactions involved in specific "red-" and "black-berry" aromas in red wines. J Agric Food Chem 57: 3702-3708. [Crossref]
12. Scanes KT, Hohmann S, Prior BA (1998) Glycerol production by the yeast Saccharomyces cerevisiae and its relevance to wine: a review. South African Journal of Enology and Viticulture 19: 17-24.

13. López de Lerma N, Peinado RA (2011) Use of two osmoethanol tolerant yeast strains to ferment must from Tempranillo dried grape: effect on wine composition. Int J Food Microbiol 145: 342-348.

14. Remize F, Roustan JL, Sablayrolles JM, Barre P, Dequin S (1999) Glycerol overproduction by engineered Saccharomyces cerevisiae wine yeast strains leads to substantial changes in by- product formation and to a stimulation of fermentation rate in stationary phase. Appl Environ Microbiol 65: 143-149.

15. Maraš V, Tomic M, Kodžulovic V, Šucur S, Raicevic J, Raicevic D, Cizmovic M (2012) Researh of origin and work on clonal selection of Montenegrin grapevine varieties cv. Vranac and cv.Kratosija. Agroznanje. I. International Symposium and XVII. Scientific Conference of Agronomists of Republic of Srpska. Trebinje. Bosnia and Herzegovina 13: $103-112$.

16. Commission regulation (EEC) No. 2676/90 determining 1990. Community methods for the analyses of wines. Official Journal of the European Union. L 272. p. 192.

17. Giusti MM, Wrolstad RE (2001) Characterization and measurement of anthocyanins by UV-visible spectroscopy. (Ed's) Wrolstad RE. Current Protocols in Food Analytical Chemistry. New York. John Wiley \& Sons, F1.2.1-F1.2.13.

18. Šucur S, Maraš V, Kodžulovic V, Raicevic J, Gazivoda A, Mugoša M, Savovic A, Košmerl T (2015) Effect of microbiological and technological parameters on Montenegrin red wines quality. Book of proceedings. Sixth International Scientific Agricultural Symposium “Agrosym 2015” Jahorina, Bosnia and Herzegovina. 260-266.

Copyright: (2016 ŠUĆUR S. This is an open-access article distributed under the terms of the Creative Commons Attribution License, which permits unrestricted use, distribution, and reproduction in any medium, provided the original author and source are credited. 